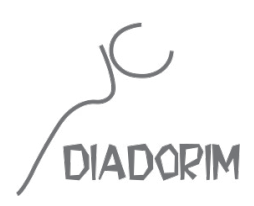

\title{
ÁLVARES DE AZEVEDO - ARIEL E CALIBAN: UMA TENTATIVA DO DUALISMO À UNICIDADE
}

\author{
Ana Rosa Gonçalves de Paula Guimarães ${ }^{1}$
}

DOI:10.17074/1980-2552.2016n17v1p49

\section{RESUMO:}

O presente trabalho apresenta uma leitura referente as diversas conceituações fundamentadas na grandiosidade do que foi o Movimento Romântico do século XVIII, ao enfatizar o contexto historicossocial, as características e atitudes pertinentes ao fazer poético e ao conceito de indivíduo desse momento, bem como suas mazelas e questionamentos acerca da existência e da arte. Logo após, foi realizado uma investigação do Romantismo brasileiro, enfocando, em especial, a obra de Álvares de Azevedo, Lira dos Vinte Anos, pertencente à terceira geração romântica, que priorizou o mal do século, o ultrarromantismo, o pesar, a dor e a melancolia. A partir dos binômios Ariel e Caliban, Azevedo, por meio da atmosfera dos paradoxos românticos, conduziu-se rumo a uma tentativa de se estabelecer a unidade perdida, o tornar-se uno do ser romântico. Foi realizada uma revisão bibliográfica utilizando o método dedutivo, que possibilitou uma melhor compreensão do tema.

PALAVRAS-CHAVE: Romantismo; Álvares de Azevedo; Dualismo; Unicidade; Subjetividade.

\section{ABSTRACT:}

This paper presents a reading concerning the various concepts grounded in the grandeur of what was the Romantic Movement of the eighteenth century, by emphasizing the historicossocial context, characteristics and attitudes relevant to the poetic and the concept of individual that moment, as well as their ills and questions about the existence and art. Soon after, we performed an investigation of the Brazilian Romanticism, focusing in particular of the work Alvares de Azevedo, Lira of Twenty Years, belonging to the third Romantic generation, which prioritized the evil of the century, the rousing romantic, grief, pain and melancholy. From the binomial Ariel and Caliban, Azevedo, through the romantic atmosphere of paradoxes, was led towards an attempt to establish the lost unity, becoming one of being romantic. A literature review was

1 Universidade Federal de Uberlândia.

Diadorim, Rio de Janeiro, Revista 17 volume 1, p. 49-65, Julho 2015. 
performed using the deductive method, which enabled a better understanding of the subject.

KEYWORDS: Romanticism; Alvares de Azevedo; Dualism; Uniqueness; Subjectivity.

\section{Aspectos da imponência do movimento romântico}

A partir do tempo e espaço que compõem determinada época, pode-se tentar entender as posturas e comportamentos realizados por seus indivíduos. Assim, o movimento romântico tem como alicerces as Revoluções Francesa e Industrial, bem como, os seus ideais propostos. O sujeito, neste período, encontra-se submerso em novos inventos e tecnologias, a partir de padrões científicos e racionais estabelecidos. Entretanto, suas emoções e inconformismos sufocados por este mesmo período, tornam-se foco de suas mobilizações e tentativas de esca/pe.

Carpeaux (1985) relata que o Romantismo, o movimento que surgiu na Alemanha por volta de 1800, conquistou logo a Inglaterra e, a partir de 1820, a França; depois todas as literaturas européias e americanas; e acabou nas tempestades das revoluções de 1848. Em seu sentido mais amplo, o Romantismo havia sido preparado por teorias filosóficas que situam a experiência na base do conhecimento humano (Locke) ou que realçam a "moral do sentimento" (Shaftersbury).

O Romantismo, como ressalta Guinsburg (1985) é antecedido pelos Séculos das Luzes, que abandonou a visão teocêntrica e teológica judaico-cristã, o qual concebia a História como um ciclo de revelação do poder divino através de Seus atos de vontade, cuja primeira manifestação seria a Gênese, ponto de partida para uma sucessão de intervenções providenciais e miraculosas ao nível do humano e terreno, cujo termo seria o Juízo Final e a instalação do reino beatífico dos justos e dos santos.

De acordo com Citelli (1993), a palavra romântico fascina e humilha, pois pode referir-se a uma atitude positiva, um gesto condenável, um sonho, ou um alimento para o pleno exercício do imaginário humano. O movimento romântico, segundo Guinsburg (1985) expande-se como uma escola, uma forma, um estado de espírito e também como um forte fenômeno histórico. Dessa forma, a configuração estética teve como antecedentes vários fatos históricos, sociais e culturais. Todavia, Citelli (1993) ressalta que, enquanto movimento, o Romantismo foi mais que um intento de ação de um grupo de poetas, romancistas, filósofos ou músicos. Tratou-se de um vasto movimento onde se asilaram o conservadorismo e o desejo libertário, a inovação formal e a repetição de fórmulas consagradas, o namoro com o poder e a revolta radical. O Romantismo foi marcado por algumas preocupações recorrentes, às quais se pode aliar certo anticlassicismo, uma visão individualista, um desejo de romper com a normatividade e com os excessos do racionalismo, em virtude dos preceitos históricos da época, cujo período corresponde aproximadamente entre o final do século XVIII e meados do século XIX, na Europa, cujo cientificismo urbano-industrial tem seu ápice.

Segundo Guinsburg (1985), observadores da vida social também perceberam o paradoxo criado pela riqueza, de um lado, e a extrema miséria, do outro, de modo que, em meio da abundância, grassava a fome provocada, muitas vezes, por crises decorrentes de um regime de produção desordenado e anárquico, estabelecido pelo liberalismo econômico. Os entusiasmos e paixões, os vôos do pensamento e do idealismo, as teorias, as aspirações e as ilusões, por contraditórias 
que pareçam e, sem dúvida, os empreendimentos artísticos da época podem ser encarados como reflexos de uma grande luz, a do Romantismo. Foi este impulso, a penetrar tudo, que elevou as energias do homem e deu a forma a um estilo distinto, que diferencia nitidamente esta época de todas as que precederam ou se lhe seguiram.

A partir do Romantismo encontramos, de um lado, o indivíduo fantasioso, imprevisível, de alta complexidade psicológica, centrado na sua imaginação e sensibilidade, gênio intuitivo investido de missão por lance do destino ou impulso inerente à sua personalidade, que é o herói romântico, encarnado de uma vontade antes social do que pessoal, apesar da forma caprichosamente subjetiva de seus motivos e decisões e, de outro lado, um ser ou organismo coletivo dotado de corpo e alma, de alma mais do que de corpo, cujo espírito é o centro nevrálgico e alimentador de uma existência conjunta.

Rosenfeld \& Guinsburg (1985b) pontuam que os românticos vêem o homem, no sentido mais profundo, o homem como um ser cindido, fragmentado, dissociado. Em função disso, sentem-se criaturas infelizes e desajustadas que não conseguem enquadrar-se no contexto social e que tampouco querem fazê-lo porque a sociedade só iria cindi-los ainda mais. Entre consciente e inconsciente, deveres e inclinações, trabalho e recompensa a brecha só poderia crescer, como parte de um afastamento cada vez maior entre natureza e espírito. Daí o sentimento de inadequação social; daí a aflição e a dor que recebem o nome geral de "mal du siècle"; daí a busca de evasão da realidade e o anseio atroz de unidade e síntese, que tanto marcam a "alma romântica".

A idéia de revolução, a absorção de pontos de vista recolhidos junto ao Iluminismo e ao Liberalismo, a crença na possibilidade de realizar a felicidade humana, animou toda uma geração romântica, situando-a na rota das grandes transformações sociais e históricas que poderiam vir a redefinir positivamente os caminhos da humanidade.

Também não seria mesmo incorreto admitir que o sentimento de descrença pudesse ter vinculações com a própria consciência da inexorabilidade das transformações urbanas, do advento de um tempo que ultrapassou a tradição agrária, da vitória de um mundo inflexivelmente racionalista e preso à lógica da matéria e do dinheiro.

Como ápice da doutrina revolucionária, o espírito do século XVIII estaria isento de regras, logo, o Romantismo existe sob a ótica de não se seguir nenhum norma. Deste modo, havia liberdade de criação, possibilidade de fundir gêneros, de misturar verso e prosa, da mesma forma como inverter o sublime ao grotesco, como faces da realidade. A liberdade de expressão reflete, com isso, a maneira do homem ultrapassar os limites do improvável e do estabelecido como meios de atingir suas aspirações frente a um mundo no qual a proposta instituída pelos seus membros é a de não estarem encarcerados em nenhum paradigma imposto por ideologias coletivas.

O Romantismo, a partir disso, despontou como um movimento contraditório, onde afirmação e negação permitem a ampliação do conflito entre o eu e o mundo, o sujeito e o Estado, deparando-se com a eclosão de uma individualidade em grau e profundidade, como nunca havia se visto (CITELLI, 1993). Portanto, a extrema emotividade, o pessimismo, a melancolia, a valorização da morte, o desejo de evasão, são apenas algumas das formas do romântico revelar sua perplexidade ante a um mundo, cujos padrões e valores ficaram inaceitáveis. Para Kiefer (1985), o Romantismo foi o rebaixamento corajoso ao universo das emoções e Vizziolli (1985) revela que o movimento libera as camadas menos conscientes da mente.

Diadorim, Rio de Janeiro, Revista 17 volume 1, p. 49-65, Julho 2015. 
Portanto, o elemento emocional acentua-se como vertente, pois revela o desejo de independência espiritual da burguesia em relação à aristocracia. Com tal postura, o indivíduo começa a possuir mais sensibilidade em decorrência do sentir mais intenso e genuíno, que de fato, talvez tenha nuances de exagero emocional, conquanto se expandindo de "dentro para fora", expõe uma atitude antiaristocrática:

Originalmente era-se sentimental e exaltado porque a aristocracia era reservada e contida; porém, logo que a intimidade e a expressividade se convertem em critérios artísticos, tornam-se valores prontamente reconhecidos pela aristocracia (CITELLI, 1993, p. 73).

Com isso, a hierarquia psicológica do Romantismo estabelece o sentimento como objeto da ação interior do sujeito, que por sua vez, transborda a categoria de humilde estado afetivo, a intimidade, a espiritualidade exercem a cobiça pelo "sentimento do sentimento ou desejo do desejo", a partir disso, verifica-se que a sensibilidade enfatiza o "amor da irresolução e da ambivalência" (NUNES, 1985, p. 52). De acordo com Citelli (1993), o Romantismo desdobrou uma tendência extremamente individualista, ou seja, o centro do mundo é o Eu. Entretanto, esta característica não se torna mero resultado da expansão do liberalismo econômico, o qual teve como fundamentos a idéia de acumulação do capital e a mentalidade concorrencial e triunfalista. Também indica o processo de despersonalização disseminado pelo jogo capitalista. Assim, o individualismo constitui-se como um processo sob o fato do homem ter sido fragmentado em suas vocações e desejos e decompondo-se em um singelo comprador de mercadorias.

O conflito do Eu com o coletivo foi detectado por Goethe, que fez parte do primeiro Romantismo alemão, denominado como Sturm und Drang - o movimento Tempestade e Ímpeto. Desta forma, o jovem Werther do referido autor, transformou-se em um paradigma do herói romântico, pela impossibilidade de se realizar amorosamente com Carlota e talvez, profundamente inadequado com o seu tempo e o seu mundo. Em uma de suas cartas, Werther escreve:

\begin{abstract}
A vida humana não passa de um sonho. Mais de uma pessoa já pensou isso. Pois essa impressão também me acompanha por toda parte. Quando vejo os estreitos limites onde se acham encerradas as faculdades ativas e investimentos do homem, e como todo o nosso labor visa apenas a satisfazer nossas necessidades, as quais, por sua vez, não têm outro objetivo senão prolongar nossa mesquinha existência; quando verifico que o nosso espírito só pode encontrar tranqüilidade, quanto a certos pontos das nossas pesquisas, por meio de uma resignação povoada de sonhos, como um presidiário que adornasse de figuras multicoloridas e luminosas perspectivas as paredes de sua célula... tudo isso, Wilhelm, me faz emudecer. Concentro-me e encontro um mundo em mim mesmo! Mas, também, aí, é um mundo de pressentimentos e desejos obscuros e não de imagens nítidas e forças vivas. Tudo flutua vagamente nos meus sentidos e, assim, sorrindo e sonhando, prossigo na minha viagem através do mundo (GOETHE, 1971, p. 19).
\end{abstract}

Assim, neste contexto evasivo do Romantismo, a vida humana se enriquece na medida em que se exacerba a vivência com imagens e através do encontro de emoções e sensações. Com isso, a dimensão concreta do existir estaria submetida à introspecção e subjetividade, pois "o mundo deve estar em mim mesmo". Portanto, para Citelli (1993, p.12), "resta a vivência interior, o reino da liberdade estaria circunscrito aos nossos próprios devaneios, ao nosso imaginário, à nossa solidão. Daí a metáfora de presidiário que consegue iluminar sua cela com as multicoloridas figuras decorrentes do sonho". Por isso, impressões e sensações organizam-se em sustentáculo 
contra a protuberante objetividade burguesa: a alma humana estaria habitada por um reino repleto de bens não qualificáveis e que nem ao menos se materializam.

O Romantismo exercitou um conceito de caça emotiva, um vôo imaginativo, cujo baluarte estaria na experiência individual, a fim de experimentar de maneira singular a racionalidade exterior e afirmar o mistério. Por conseguinte, o verbo imaginar, quase sinônimo de fuga do real, ou até mesmo termos mais depreciativos, inclui: ideal, ilusório, falsidade, utópico, virtual, convite à loucura, entre outras. Citelli (1993), afirma que o Romantismo foi repercurssor do rompimento da faceta embaraçosa da imaginação. Assim, o apelo à subjetividade, denota-se como libertária, inspirando gênios "a missão de separar um mero imitador de modelo de um original inventor de objetos artísticos".

Sob o plano subjetivo, a realização amorosa era sentida como uma vivência genuína, embora impossível para ser concretizado em um mundo fragmentado. A fuga, a evasão, o ilogismo, a presença de uma visão amorosa, desta forma, assumiram a forte extração platônica. Por isso, o amor romântico prevaleça como força redentora e reintegradora, tanto do homem como da mulher, pela preservação da autenticidade dos sentimentos. Para Vizziolli (1985), na influência platônica, a imaginação incumbiu-se de colocar o homem com o ideal e contemplá-la, tornando-a o mais eficiente estímulo moral.

A tendência dos casos de família, tendo sua miragem na vulgaridade do destino das criaturas humanas é superado por idéias de felicidade e harmonia ou até mesmo o final hollywoodiano ao se salvar a unidade da família, do casamento e promulgar o final "felizes para sempre", com isso concretiza a subjetividade aliada a imaginação. Como exemplo, vale destacar Senhora, de José de Alencar.

Ao penetrar no âmago da realidade, Rosenfeld \& Guinsburg (1985a, p. 286) concluem que a imaginação penetra nos espaços mais intensos do Eu e se desencadeiam rompendo barreiras, uma floresta selvagem - o inconsciente. Os românticos, assim, se sentem atraídos por esta região profunda do ser, porque as dissociações, associações, fragmentações que se cindem ou desintegram, fazem domínio da expressão poética e de um reino encantando, o qual não há a racionalidade e nem as leis cotidianas. Por isso, Shelling expõe: "No fundo, eu e a natureza somos idênticos"; ou como Novalis: "Reencontro-me no universo, assim como encontro o universo em mim". Também pontua: "Preciso apenas penetrar no imo de meu ser, na centelha de minha alma, por assim dizer, na alma de minha alma, para chegar àquela força espiritual que está dentro de mim, que é ao mesmo tempo o universo.

O choque entre o Eu e o mundo, a tensão irreconciliável entre uma sociedade cada vez mais afirmadora da divisão de trabalho e do domínio do capital e o artista romântico incapaz de se ajustar, implica em temas vinculados à fuga da realidade. Portanto, o retorno ao $\mathrm{Eu}$, a intensificação do elemento subjetivo, ou a expansão dirigida a um tempo medieval ou exótico. Nestes encadeamentos, temas como a valorização da morte, a exaltação religiosa e a natureza como elemento regenerador e ideal, talvez neutralizem o permanecer do homem na sociedade (CITELLI, 1993).

O grotesco desabrocha em decorrência das camadas do ser, pois sempre que se produz alguma desordem, o homem percebe-se inábil de exercer qualquer função restauradora, então ocorre um fenômeno estilístico do grotesco e as camadas ontológicas se mesclam. Assim, nota-se o fenômeno na figura de Quasímodo, de Victor Hugo, cujo intuito é enaltecer e expressar as nuDiadorim, Rio de Janeiro, Revista 17 volume 1, p. 49-65, Julho 2015. 
ances das contradições entre a aparência e o desejável para o próprio ser, o modelo promulgado pela cultura e a busca por rompê-lo (ROSENFELD; GUINSBURG, 1985b, p. 292). Tal mecanismo decorre em virtude da identificação do sujeito com os excluídos.

Sendo sentido que o presente não é um tempo agradável, e o sujeito estar margeando por instituições opressoras, umas das alternativas foi recuperar e retornar ao passado, em especial ao mundo medieval, repleto de lendas e mistérios, haja visto que o adjetivo romântico é derivado do substantivo romaunt (roman ou romant), o qual designa romances medievais e de cavalaria. Notoriamente vários romances são calcados nesta tradição, cujos temas estão ligados às aventuras do rei Arthur e os cavaleiros da Távola Redonda, como Ivanhoé de Walter Scott as lutas medievais baseadas em Eurico, o Plesbitero de Alexandre Herculano. Até mesmo o herói indianista de José de Alencar adota princípios como a honra, a dignidade e a coragem.

As naturezas idealizadas e dinâmicas equivaleram a sinônimo de certificação nacional. Para Citelli (1993), de certa forma, os românticos confundiram os conceitos de terra, nação, dimensão física e dimensão política, pois generalizaram que se a terra fosse boa, logo a nação também deveria ser. A partir disso, as florestas viraram símbolos, pois, no Brasil como sua natureza, poderia vir a ser um paraíso futuro. Por isso, ao se enlevar a natureza, estar-se-ia fazendo do mesmo modo com a pátria. Assim, na trilogia de José de Alencar, Ubirajara, Iracema e $O$ Guarani, muitas vezes caíram na estereotipia, na queda do exótico para o deslocamento a um lugar utópico, segundo o mesmo autor para o encontro de uma "visão rosseauniana".

Através do processo de sublimação, o comportamento prende-se à natureza, pois os temas como amor e poder, por sua vez, são condensados em erotismo e satanismo (NUNES, 1985). Quanto ao satanismo, o homem, então, não seria o único agente responsável pela sua condição no universo, sofreria interferências de Deus, quando assim obtivesse êxito em suas metas e, caso transcorresse alguma adversidade, estaria subjugado por Lúcifer.

A atitude do romântico confunde-se com a psicologia do adolescente, quanto à liberdade, paixão e emoção manifestadas com teores intensos e dilatados, embora tenha se solidificado por meio do homem maduro. Outro equivalente da mentalidade romântica é oferecido pela psicologia feminina, visto que a compreensão de determinado problema, embaraça a oferta da complexidade da apresentação, levando a excluir aspectos culturais, históricos e filosóficos do Romantismo, expelindo-se de seu horizonte especifico (BORNHEIM, 1985).

De acordo com Candido (1986), o espírito noctívago é um dos traços mais típicos do Romantismo e essencial para sentir a atmosfera do poema, pois o gosto pela noite traduz o mistério, o sombrio e finda uma hora em que os acontecimentos sobrenaturais, acoplado à imaginação, são associados. Também, o "gosto pela noite da alma" desvenda o modo de ser do melancólico ou lutuoso, cuja dominação ocorre através das forças incontroláveis, inconscientes. Portanto, na noite, a imaginação romântica desdobra-se em um mundo provocando uma transmutação da maneira de ver e conceber, tanto o mundo exterior, quanto interior. Para Rosenfeld; Guinsburg (1985a), o elemento noturno avalia alguma expressão selvagem e também patológica, refletindo, através disso, a inclinação mórbida.

O Romantismo apresenta um duplo contraste, pois há um saudoso olhar disseminado ao passado, embora, também haja uma atribulação ao deparar-se com o presente. Segundo Bornheim 
(1985, p. 213): “a nostalgia não é como pretendem certos autores, um fenômeno primeiro do Romantismo. Inicialmente é o sentido do infinito, do absoluto, interior à alma humana, condenada à sua finitude, e que se expressa sob a forma de nostalgia". A nostalgia reflete o desejo de reconquistar o infinito: "[...] devemos algum dia, nos tornar onipresentes, todos uns nos outros, sem, contudo, sermos unidade. Pois unos não nos devemos tornar porque, então, o esforço para atingirmos a unidade cessaria”.

\section{O romantismo no Brasil e a atmosfera dual}

O Romantismo no Brasil, de acordo com Roncari (2002), é compreendido entre o período que vai de 1836, o qual foi o ano de lançamento da revista Niterói, até 1837, o ano da morte de Castro Alves. Nesse momento, a época romântica coincidiu com a Independência política do país, em 1822, o que, possibilitou a independência cultural do Brasil, a assunção de uma identidade cultural e uma produção literária mais efetiva.

A valorização das populações indígenas, o índio como heroi nacional - correspondente ao cavaleiro medieval, que vivia em grandes espaços de florestas selvagens, eram idealizados e vistos com bons olhos, uma vez que, a influência do "bom selvagem" de Rousseau fez-se presente na essência do Romantismo brasileiro.

A literatura esteve presente nos principais meios de formação da opinião: em jornais, nos púlpitos e nas tributas políticas, pois era considerada uma concretude, a fim de soldar as opiniões na construção da nacionalidade. A partir da difusão e ordenamento da língua, elegiam-se valores característicos da nacionalidade, como também, aos homens livres de todas as regiões do país, a possibilidade de identificar-se com os seus. Com isso, a cultura passa a ser sinônima da língua.

Para Roncari (2002), o poeta romântico é um inconformista, pois, lamenta não apenas os limites da natureza humana e a falta de contato com o Absoluto, como critica o mundo burguês em que vive, onde as coisas são medidas pelo valor quantitativo. O poeta assumiria no Romantismo, o papel que o sacerdote adotou na sociedade tradicional. Entretanto, ele é acessível e permite que outros mergulhem no divino, isto é, seria mediador do conhecimento e sua missão era a de transmitir ideias. A poesia reflete os grandes acontecimentos, que se espelharia das ideias, passando às coisas, como também acena aos séculos, aos povos e aos impérios.

O Romantismo surge como um movimento de negação, que, para Candido (1981a), seria a ruptura com a literatura portuguesa, uma vez que, profunda e revolucionária, a literatura nacional visou redefinir o lugar do homem no mundo e na sociedade, a partir de sua identificação nacional. Esse novo estado de consciência, cujos traços mais salientes são o conceito de indivíduo e o senso de história, o qual busca, por meio das atitudes românticas do individualismo e relativismo, uma caça rumo ao Eu Absoluto.

A primeira geração da poesia romântica brasileira tem como seu maior representante, Gonçalves Dias, que como, características, adotou a influência da tradição portuguesa clássica, a lírica, a invenção do significante e o saudosismo. A segunda geração vem simbolizada por Álvares de Azevedo, cujas temáticas envolvem o "mal do século", o fantástico, a melancolia e a morbidez. Já a terceira geração, tem-se Castro Alves, poeta que deu voz às questões sociais, celebrava a vida e o amor erótico (RONCARI, 2002). 
Como um movimento do ser adolescente, no Brasil, seu maior representante foi o poeta Álvares de Azevedo, segundo Candido (1981b). O adolescente, muitas vezes, é dividido, não raro ambíguo, advertido por dilaceramentos, assim como o poeta, que, em cuja personalidade literária mistura-se a ternura casimiriana e nítidos traços de perversidade. Há o desejo de afirmar a submissão e o temor de menino amedrontado; a rebeldia dos sentidos, que eleva à extrema idealização da mulher, e de outra, a lubricidade que a degrada. Rebeldia esta, que por vezes, batalha os sexos no seu ímpeto cego, fazendo Satã inclinar-se pensativo sobre Macário desfalecido e o próprio poeta mascarar-se de mulher, em um baile, negando a noite toda um admirador equivocado.

Álvares de Azevedo, de acordo com as contribuições de Candido (1981b), sofreu como o adolescente, no entanto, era fascinado pelo conhecimento e se atirou aos livros com ardor; mas, ao mesmo tempo foi suspenso pela obsessão de algo transcendente, a que não ousou entrega-se. Há nele, sobretudo, a adolescência, aquele misto de frescor juvenil e fatigada senilidade, presente nos jovens do Romantismo.

Azevedo, no conto fantástico Noite na Taverna (2008, p. 35), expressa sua percepção sobre o homem e a existência, cuja transitoriedade é o foco de suas inquietações, revolta e um sentimento de ausência. No entanto, a falta implica em algo que anteriormente houvera-se estado presente, como a juventude e as ilusões:

O que é o homem? É a escuma que ferve hoje na torrente e amanhã desmaia, alguma coisa de louco e movediço como a vaga, de fatal como o sepulcro! O que é a existência? Na mocidade o é caleidoscópio das ilusões, vive-se então a seiva do futuro. Depois envelhecemos: quando chegamos aos trinta anos e o suor das agonias nos grisalhou os cabelos ante o tempo e murcharam, como nossas faces as nossas esperanças, oscilamos entre o passado visionário e este amanhã do velho, gelado e ermo depois como um cadáver que se banha ante de dar à sepultura! Miséria! Loucura!

Sendo assim, o desenrolar do tempo produz um sentimento de nostalgia decorrente de uma dilacerada sensação de impotência, que se demarca em uma contínua e abalada ameaça de despenhar-se. Freud em "Sobre a Transitoriedade" (1916 [1915]), analisa os lamentos de um poeta, cujo pensamento recai, invariavelmente, a fadada extinção da beleza, seja ela o esplendor humano, bem como a Natureza que se faz destruída pelo inverno. Por isso, tudo que se constitui como belo, ao cair em decadência, leva o sujeito a um penoso desalento e rebelião frente ao valor dado pela escassez do tempo e ao significado poderoso da destruição. A duração da harmonia natural é condicionada à vida emocional de cada indivíduo, que, assim, dará o tom e o definido espaço atmosférico para sua plenitude ou aniquilamento. Pelo fato de possuirmos uma dose generosa quanto à capacidade de amar, que se denomina libido, os objetos danificados derivarão do luto decorrido da morte de toda a beleza e, a partir disso, a energia novamente é liberada, mesmo que protelada poderá substituí-lo por outros ou retornar de maneira provisória ao ego. Quando o ego, finalmente, renunciar o objeto perdido e a idealização encravada no mesmo, conseguirá averiguar o alto conceito das riquezas do mundo e organizará em seu Eu o mérito do efêmero.

O cansaço precoce de viver, o desejo pelo fim, assaltaram com frequência a imaginação de Álvares de Azevedo, com o qual, foi atraído pela sensualidade e ao mesmo tempo afastado pelo crepúsculo moral e pela imagem punitiva da mãe, conduzindo a uma idealização que acarretou com contrapeso, em muitas vezes, a imaginação, a nostalgia, o vicio e a revolta. Morrendo aos vinte e um anos, o poeta, teve o privilegio de corporificar as várias tendências psíquicas de uma 
geração, concentrando em si o peso do que se repartia em porções nos demais poetas (CANDIDO, 1981b).

De todos os românticos famosos, Byron exerce influência mais profunda sobre os seus contemporâneos e, sobretudo em Álvares de Azevedo. Para Hauser (1998) através das temáticas do desassossego e do desnorteio românticos convertem-se numa praga, o "mal do século"; o sentimento de isolamento transforma-se em um culto ressentimento da solidão, a perda da fé nos antigos ideais redunda em um individualismo e o tédio converte-se no namoro com a vida e com a morte. Álvares como Byron conferem um encanto sedutor à maldição de sua geração e converte-se seus heróis em exibicionistas que expõe ostensivamente suas feridas, em masoquistas, que publicamente se carregam de culpa e vergonha, flagelantes que se atormentaram com autoacusações e inquietações de consciência, e confessam suas boas e más ações com o mesmo orgulho intelectual de posse.

Em Lira dos Vinte Anos (2008), coletânea de poemas de Álvares de Azevedo, é uma obra dividida em três partes, sendo estas constituídas: pela primeira - Ariel; a segunda parte - Caliban e, a terceira parte correspondente a poemas encontrados depois de sua morte.

Segundo o prefácio da obra da primeira parte, Azevedo (2008, p. 13) destaca que os poemas são compostos por cantos de um pobre poeta, cujas "primeiras vozes do sábia não têm a doçura dos seus cânticos de amor. É uma lira, mas sem cordas: uma primavera, mas sem flores, uma coroa de flores, mas sem viço". São significações de sonhos dissipados pela existência, vibrações emocionais, onde a musa seria a própria poesia, por meio de um tom idealizado, positivo, idealista. Essa parte configura-se por Ariel - o bom, o puro.

Já no prefácio da segunda parte da Lira dos Vinte Anos, Álvares (2008), oferecerá o nome de Caliban - o mal. Segundo o autor (2008), a unidade do livro, fundamenta-se na binômia, em que duas almas que habitam nas cavernas de seu cérebro, que escreveram o livro. A primeira parte representaria o espírito, a abstração; enquanto, a segunda, abarcaria o carnal, o concreto. Candido (1981b) ressalta que a segunda parte da lira mostra a força do sarcasmo do poeta, o qual a sua poesia despertaria prazeres, e desvendaria a dialética segundo a qual os contrastes favorecem a verdadeira realização do artista.

Nota-se, desse modo, no Romantismo, que é proposto o phatos de um novo começo, por meio da experiência de conversão, ao voltar-se para a interioridade. O estilo romântico, assim como, para a proposta poética de Álvares pode ser definido por um sentimento de ruptura, o qual foi vivido como perda, ou ainda o movimento buscou a unidade perdida, ou seja, Ariel e Caliban deveriam tornar-se, por meio da binômia, dos dualismos - para almejar a unidade, o tornar-se uno.

Como tentativas de resgatar a unicidade perdida, homem, Deus e Universo consistiriam um Todo, a forma, o centro, o gérmen, onde a divindade estaria no meio e entre todos. A indistinção entre sujeito e objeto seria fundida no homem, por meio da Natureza, onde se deixava de existir a distinção, assim como foi rebaixado o que era elevado e elevou-se o que era baixo; sacralizou o profano e tornou o profano sagrado. Como poema da primeira parte - Ariel, AT.., Azevedo (2008. p. 45), destaca o amor puro e idealizado. O eu-lírico constroe imagens para construir a mulher - virgem, em uma atmosfera de sonho e devaneio. 
A T...

No amor basta uma noite para fazer de um homem um Deus.

Amoroso palor meu rosto inunda, Mórbida languidez me banha os olhos, Ardem sem sono as pálpebras doridas, Convulsivo tremor meu corpo vibra... Quanto sofro por ti! Nas longas noites Adoeço de amor e de desejo

E nos meus sonhos desmaiando passa A imagem voluptuosa da ventura:

Eu sinto-a de paixão encher a brisa, Embalsamar a noite e o céu sem nuvens;

E ela mesma suave descorando.

Os alvacentos véus soltar do colo, Cheirosas flores desparzir sorrindo Da mágica cintura.

Sinto na fronte pétalas de flores, Sinto-as nos lábios e de amor suspiro... Mas flores e perfumes embriagam... E no fogo da febre, e em meu delírio Embebem na minhalma enamorada Delicioso veneno.

Estrela de mistério! Em tua fronte Os céus revela e mostra-me na terra, Como um anjo que dorme, a tua imagem

$E$ teus encantos, onde amor estende Nessa morena tez a cor de rosa.

Meu amor, minha vida, eu sofro tanto!

$\mathrm{O}$ fogo de teus olhos me fascina,

$O$ langor de teus olhos me enlanguece,

Cada suspiro que te abala o seio

Vem no meu peito enlouquecer minhalma!

Ah! Vem, pálida virgem, se tens pena De quem morre por ti, e morre amando,

Dá vida em teu alento à minha vida, Une nos lábios meus minh'alma à tua! Eu quero ao pé de ti sentir o mundo $\mathrm{Na}$ tu'alma infantil; na tua fronte Beijar a luz de Deus; nos teus suspiros

Sentir as virações do paraíso...

E a teus pés, de joelhos, crer ainda

Que não mente o amor que um anjo inspira,

Que eu posso na tu’alma ser ditoso,

Beijar-te nos cabelos soluçando

E no teu seio ser feliz morrendo!

O amor à amada associa-se ao tema do amor divino, como no romance de F. Schlegel, Lucinda. 
Da mesma forma, os cantos eróticos-espirituais de Novalis, feitos sob os moldes dos cantos pietistas, dedicados à Virgem Maria, nos quais, por exemplo, são venerados os seus sagrados seios. Esta religião romântica rejeita as censuras da crítica moralizadora, leva a extremos as suas tendências, como, por exemplo, em relação ao tema de salvação: para os românticos, da mesma forma, não poderia haver uma verdadeira salvação sem que existisse, igualmente, a possibilidade da perdição. Como dirá Novalis; “o pecado é o maior estímulo para o amor da divindade. Quanto mais nos sentimos pecadores, mais nos sentimos cristãos. O objetivo do pecado e do amor é a união total com a divindade" (apud ANDRADE, 2011, p. 57). Nesse cenário, Musset (2008, p. 143) descreve:

A curiosidade do mal é uma enfermidade infame, que nasce de todo o contato impuro. É o instinto vagabundo dos fantasmas, que levanta a pedra dos túmulos; é uma tortura inexplicável com que Deus pune os que pecam. Eles desejam crer que tudo falha e todos pecam; e se fosse assim, talvez ficassem desolados.

Contudo, o papel desempenhado por Eva, em referência à expulsão do Paraíso, cria um vínculo e um cenário escatológico entre a mulher e o maligno e, consequentemente, transforma-a em uma tentadora e corruptora dos homens. Embora, a reintrodução do culto à Virgem pelo pietismo irá contribuir para a revalorização da figura feminina na cultura alemã. Adão, entretanto, representou o amor à matéria e à primitividade.

Inicialmente, o pietismo reflete no século XVII, o desencantamento de uma época em relação ao desenvolvimento tomado pelo protestantismo, como, também, à ortodoxia que transformava e adulterava o espírito de piedade cristã pregado originalmente por Lutero. Seu objetivo foi o de promover uma regeneração, a partir do seu próprio interior, ao mesmo tempo em que aceita as formas já instituídas, mesmo considerado-as imperfeitas. Para Andrade (2011), no pietismo, o sujeito estava em permanente escuta de si mesmo, a fim de revelar um saber sobre si, o que denotaria a análise profunda de seu Eu, a partir de um movimento de constante introspecção e por meio da busca de Deus, o que tornaria assim, indissociável do autoconhecimento e da sua própria subjetividade. Goethe transformará um de seus contatos de juventude com o pietismo em tema de um livro que, se não é inteiramente romântico, entretanto, tornar-se-á o romance-chave da estética romântica, Os anos de aprendizagem de Wilhelm Meister, o seu livro VI - Confissões de uma bela alma, segundo Andrade (2011, p. 47):

Constitui o capítulo religioso deste romance, mas também um importante documento sobre a evolução deste movimento na Alemanha. Em oposição à problemática da salvação, o pecado reveste-se de uma conotação positiva, no sentido de que, somente através dele pode se chegar à salvação, como reflete, no romance Os anos de aprendizagem de Wilhelm Meister, a posição do abade pietista que preferia os fiéis que tinham se desviado de seu próprio caminho aos que nunca o haviam feito. Estes desvios de fé têm o poder de mostrar ao fiel o bom caminho - a revelação: a conversação do ser à verdade divina.

O Romantismo é uma forma de gnose, a qual nasce da incompreensão ligada ao mal substancial e ao mal do mundo, o qual é a existência, em que os seres individuais romperam com a unidade divina e com as barreiras do ser, como também, Romantismo e gnose são análogos quanto ao dualismo pessimista e sentimental. A gnose propõe que a religião seja o conhecimento, que por sua vez, é salvador. A revelação é intrínseca e do homem a Deus e de Deus ao homem, como uma das formas de retorno a unidade primitiva; pois, o homem teria vocação ao sublime e seria 
divino de Natureza. Também, o Romantismo é ecumênico [toda terra habitada], cuja proposta era de que todas as religiões se equivalessem e, a Igreja deveria ser pobre e igualitária, porque, buscava propiciar a manifestação da divindade em todo e qualquer indivíduo. A única realidade real seria a interioridade - a divindade aprisionada. Assim, paradoxalmente, o Romantismo alargou e reduziu a velocidade do sentido religioso.

No entanto, em conseqüência da revalorização do pecado, há a recuperação de umas das figuras mais importantes do panteão da mitologia romântica, isto é, do imaginário que se alimentará esta mitologia - já que o Romantismo também se colocava como uma mitologia da razão a serviço das ideias - como afirmará Schelling (apud ANDRADE, 2011, p. 57). A figura a que referida é a do Maligno, do demônio, cuja presença firma e serve de apoio à função escatológica atribuída ao pecado, inicialmente pelo pietismo e, ulteriormente pelo Romantismo. O século das Luzes, século da razão, tendeu a eliminar do espírito humano os menores traços do demoníaco, uma vez que a razão se impunha à ignorância das crenças impostas e das superstições, da mesma forma que dos desvios da paixão, da imaginação e da fantasia.

Coligado com a perspectiva do mistério e do insondável, o Romantismo dedicou-se determinantemente com a valorização do Eu e da morte. Citelli (1993) ressalta que a fim de se afastar de um mundo incompleto e desajustado, o romântico opta pela morte, como forma gloriosa, gesto definitivo e radical revelar uma profunda indisposição com a sociedade. A morte tornou-se um tema comum em quase todo Romantismo, e também, em Álvares de Azevedo, revestindo-se de maior ou menor dose de lirismo, ora remetendo a uma visão mais ingênua, ou a uma crueldade demoníaca. Há textos românticos sobre a morte que praticamente celebrizaram alguns autores, como no caso, por exemplo, do português Soares Passos e seu O noivado do sepulcro, que foi um verdadeiro mapa da morte e do cemitério.

Portanto, a cosmovisão é norteada através das ilusões e fantasias, que por sua vez, fulguram por meio da assimilação com personagens planas e maniqueístas. Contudo, a morte no Romantismo, em geral denota união, libertação, esperança de sobrevivência, a partir dos paradoxos vivenciados em um mundo injusto, como observado no poema No túmulo do meu amigo João Baptista Da Silva Pereira Júnior, de Azevedo, (2008, p. 67), também da parte Ariel:

\section{NO TÚMULO DO MEU AMIGO \\ JOÃO BAPTISTA DA SILVA PEREIRA JÚNIOR \\ EPITÁFIO}

\footnotetext{
Perdão, meu Deus, se a túnica da vida... Insano profanei-a nos amores! Se à coroa dos sonhos perfumados Eu próprio desfolhei as róseas flores!

No vaso impuro corrompeu-se o néctar, A argila da existência desbotou-me! O sol de tua gloria abriu-me as pálpebras, Da nódoa das paixões purificou-me! 
Tudo calou-se pela noite eterna...

E eu vago errante e só na treva infinda...

Alma em fogo, sedenta de infinito,

Num mundo de visões o vôo abrindo,

Como o vento do mar no céu noturno

Entre as nuvens de Deus passei dormindo!

A vida é noite: o sol tem véu de sangue:

Tateia a sombra a geração descrida...

Acorda-te, mortal! é no sepulcro

Que a larva humana se desperta à vida!

Quando as harpas do peito a morte estala,

Um treno de pavor soluça e voa:

$\mathrm{E}$ a nota divinal que rompe as fibras

Nas dulias angélicas ecoa!

Embora sob as fatalidades circunscritas na sociedade em que se vive o romântico, muitas vezes mergulha na melancolia e na aceitação da sua infelicidade, exprimindo-se num lirismo terno, evocador e, também, muitas vezes mórbido e sombrio. A melancolia noturna e tumular satisfaz à catarse e ao desejo de depender. Derramam-se múltiplas lágrimas, embora o choroso também tenda ao "sorriso entre lágrimas", ou seja, ao humor.

O Saint-Preux, de Rousseau, e o Werther, de Goethe foram as primeiras obras que concretizaram a desilusão que se apoderou do espírito humano na era romântica, enquanto o René, de Chateaubriand, é a expressão do desespero em que o desengano se converteu. O sentimentalismo e a melancolia do pré-romantismo estavam de acordo com o estado emocional da burguesia antes da Revolução, enquanto o pessimismo e o cansaço vital da literatura emigré concordava com o estado de ânimo da aristocracia depois da Revolução (HAUSER, 1998). O desajustamento, o dualismo entre gênio e Satã, que causa mal-estar e a atmosfera mórbida e mesmo melancólica, pode ser observada em Um Cadáver de Poeta (AZEVEDO, 2008, P. 115):

UM CADÁVER DE POETA

$$
\text { [...] }
$$

\section{O Desconhecido}

\footnotetext{
"Quem sou? um doudo, uma alma de insensato Que Deus maldisse e que Satã devora! Um corpo moribundo em que se nutre Uma centelha de pungente fogo! Um raio divinal que dói e mata, Que doira as nuvens e amortalha a terra!... Uma alma como o pó em que se pisa! Um bastardo de Deus! um vagabundo A que o gênio gravou na fronte - anátema! Desses que a turba com o seu dedo aponta... Mas não; não hei de sê-lo! eu juro n’alma, Pela caveira, pelas negras cinzas De minha mãe o juro!... Agora há pouco, Junto de um morto reneguei do gênio, Quebrei a lira à pedra de um sepulcro...

- Eu era um trovador, sou um mendigo..."
} 
Os Românticos, portanto, tinham obsessão pelo locus horrendus (lugar horrível, feio, sóbrio e que provoca horror). Os cenários para as histórias, geralmente apresentavam-se em cemitérios, catacumbas, mausoléus, túmulos, casarões/mansões/castelos assombrados abandonados ou em ruínas, florestas escuras, cavernas, grutas, prisões, masmorras, câmaras de tortura, porões e pântanos. Há a presença de uma fauna característica com animais asquerosos: sapos, baratas, vermes, ratos, lagartixas, lagartos; de animais peçonhentos, como cobras, mochos, corvos, escorpiões, aranhas, lacraias e animais de mau-agouro, como corujas, corvos, urubus, gatos-pretos, morcegos, sapos. O poema A Lagartixa, de Azevedo (2008, p. 155), da segunda parte da obra, representa uma imagem rebaixada, pois a lagartixa é um animal rastejante, como também, a comparação entre travesseiro e peito sugere a ironia.

IV

A Lagartixa

\footnotetext{
A lagartixa ao sol ardente vive

E fazendo verão o corpo espicha:

O clarão de teus olhos me dá vida,

Tu és o sol e eu sou a lagartixa.

Amo-te como o vinho e como o sono,

Tu és meu copo e amoroso leito...

Mas teu néctar de amor jamais se esgota,

Travesseiro não há como teu peito.

Posso agora viver: para coroas

Não preciso no prado colher flores,

Engrinaldo melhor a minha fronte

Nas rosas mais gentis de teus amores.

Vale todo um harém a minha bela,

Em fazer-me ditoso ela capricha...

Vivo ao sol de seus olhos namorados,

Como ao sol de verão a lagartixa.
}

O sonho em Álvares, para Candido (1981b) é tão forte quanto a realidade; os mundos imaginários são tão atuantes quanto o mundo concreto e a fantasia se torna experiência viva que pode causar sofrimento ao eu-lírico. Marcante pelo grotesco e por os amores tangíveis, o poeta se exime deles, recuando-se para o impossível, o inatingível, da mesma forma que fez com os demais por meio da idealização extremada. A mulher adormecida, para Candido (1986), gisgnifiou a manifestação do medo de amar do poeta, como a prostitua relatada, em terceira pessoa, seria pálida, bela, um anjo poluído que realizaria as fantasias carnais do poeta.

O platonismo constitui um dos horizontes filosóficos do romantismo, de acordo com Andrade (2011), o qual acarretará o renascimento do mito do andrógino: o ser híbrido, completo e perfeito. Imortal, posto ser capaz de se auto-engrendar, porém devido à sua cisão, na origem dos tempos, dará origem à oposição dos dois sexos, onde cada um traz em si a nostalgia da unidade primeira. A subjetividade unificada, no entanto, é cindida, dividida em sua unicidade, tentando desesperadamente unir seus antípodas. A produção romântica faz-se, consequentemente, a partir da tentativa de fusionar os opostos em todas as suas manifestações. 


\section{Desânimo}

Estou agora triste. Há nesta vida

Páginas torvas que se não apagam,

Nódoas que não se lavam... se esquecê-las

De todo não é dado a quem padece...

Ao menos resta ao sonhador consolo

No imaginar dos sonhos de mancebo!

Oh! voltai uma vez! eu sofro tanto!

Meus sonhos, consolai-me! distraí-me!

Anjos das ilusões, as asas brancas

As névoas puras, que outro sol matiza.

Abri ante meus olhos que abraseiam

E lágrimas não tem que a dor do peito

Transbordem um momento..

E tu, imagem,

Ilusão de mulher, querido sonho,

Na hora derradeira, vem sentar-te,

Pensativa e saudosa no meu leito!

O que sofres? que dor desconhecida Inunda de palor teu rosto virgem? Por que tu'alma dobra taciturna,

Como um lírio a um bafo d’infortúnio? Por que tão melancólica suspiras?

Ilusão, ideal, a ti meus sonhos,

Como os cantos a Deus se erguem gemendo!

Por ti meu pobre coração palpita...

Eu sofro tanto! meus exaustos dias

Não sei por que logo ao nascer manchou-os

De negra profecia um Deus irado.

Outros meu fado invejam... Que loucura!

Que valem as ridículas vaidades

De uma vida opulenta, os falsos mimos

De gente que não ama? Até o gênio

Que Deus lançou-me à doentia fronte,

Qual semente perdida num rochedo,

Tudo isso que vale, se padeço!

Nessas horas talvez em mim não pensas:

Pousas sombria a desmaiada face

Na doce mão e pendes-te sonhando

No teu mundo ideal de fantasia...

Se meu orgulho, que fraqueia agora,

Pudesse crer que ao pobre desditoso

Sagravas uma idéia, uma saudade..

Eu seria um instante venturoso!

Mas não... ali no baile fascinante,

$\mathrm{Na}$ alegria brutal da noite ardente,

No sorriso ebrioso e tresloucado

Daqueles homens que, pra rir um pouco,

Encobrem sob a máscara o semblante,

Tu não pensas em mim. Na tua idéia

Se minha imagem retratou-se um dia

Foi como a estrela peregrina e pálida

Sobre a face de um lago...

(AZEVEDO, 2008. p. 189). 
O poema Desânimo, com isso, expressa o desejo insatisfeito e indefinido, o homem romântico sublinhou-se ao satanismo, como forma de conhecimento, poder às causas de conflitos dramáticos e teológicos, com o qual, pactua de sua vontade própria, e contra quem se debate, Lúcifer, anjo caído de Deus, instiga a sede do poder e do conhecimento, a fim de tornar a consciência, tal como Manfredo, de Byron, presa da morte e da consciência da culpa. Adversário e aliado, antagonista necessário que transfigura a árvore do Bem e do Mal na árvore da vida, ao desencorajar o homem, a infringindo as interdições de Deus-Pai, defronta-se com o seu destino e com a morte, Satã, fonte do vigor do espírito e da imaginação para William Blake, (apud Nunes, 1985, p. 73). "aquele que fala aos homens, nos desejos do coração e nos sonhos da alma" (Vigny), é o símbolo maior da sequiosidade ambivalente da alma romântica, de sua introversão, de seu desdobramento interno, do conflito entre as suas aspirações ideais e sua impotência real. Símbolo de tudo que O Primeiro Fausto de Goethe, captou e sintetizou como trágico embate do destino humano. Conforme salienta Nunes (1985), a ascensão e o decesso, a subida e a queda vertiginosas, tipificam, na lírica e no romance, a conduta espiritual dos românticos, que acompanharam a "turbulência fáustica" em que se forjou o "escudo de sublimação ou do ideal do eu".

Álvares de Azevedo em sua obra, e em especial na coletânea de poesias Lira dos Vinte Anos, por meio de Ariel e Caliban expressão e compõem a evanescência de passagem do consciente para o inconsciente, do definido para o indefinido, do concreto ao abstrato, da solidão ao vaporoso, que aparece na visão da natureza. Uma vez que, o poeta trata de binômios, de dualismo, paradoxos, temática típica do Romantismo, assim como no movimento, a principal ambição de Azevedo foi atingir a superação desses dualismos.

O conflito interior da alma romântica se reflete de modo direto e expressivo à figura do "segundo eu", que está sempre presente ao espírito romântico e repete-se em inúmeras formas e variações na literatura também romântica. A fonte desta ideia fixa, segundo Hauser (1998) vem por meio do impulso à introspecção, na qual é uma tendência de auto-observação e compulsão do indivíduo rumo ao desconhecido, ao estranho e ao remoto. Também pode representar uma tentativa de evasão dos românticos para se submeterem a aceitar sua própria condição histórica e social. Tal duplicidade precipita-se a tudo que seja obscuro e ambíguo, caótico e extático, demoníaco e dionisíaco, e busca a partir disso, o refúgio de realidade que é incapaz de dominar por meio racionais. Nessa fuga da realidade, descobre-se o "inconsciente", aquilo que está oculto e, seguro para a mente racional, a origem de seus sonhos de realização de desejos e das soluções irracionais de seus problemas. Descobre que o habitar de duas almas em um mesmo corpo, que carrega seu demônio e seu juiz. O autor (1998) ainda afirma que se descobre, neste momento, a psicanálise.

\section{Referências}

ANDRADE, R. A face noturna do pensamento freudiano: Freud e o Romantismo alemão. Niterói: EduFF, 2000.

AZEVEDO, A. Lira dos vinte anos. São Paulo: Editora Martin Claret, 2008.

AZEVEDO, A. Noite na Taverna/Macário. São Paulo: Martin Claret, 2008

BORNHEIM, G. "Filosofia do Romantismo". In: GUINSBURG, J. (Org.). O Romantismo. São Paulo: Perspectiva, 1985. 
CANDIDO, A. O Romantismo como posição do espírito e da sensibilidade. In: Formação da Literatura Brasileira: Momentos Decisivos. 6 ed. Belo Horizonte, Itatiaia, 1981a.

CANDIDO, A. Álvares de Azevedo ou Ariel e Caliban. In: Formação da Literatura Brasileira: Momentos Decisivos. 6 ed. Belo Horizonte, Itatiaia, 1981b.

CANDIDO, A. Caderno de análise literária. 2a ed. São Paulo: Ed. Àtica, 1986.

CITELLI, A. Romantismo. 3. ed. São Paulo: Àtica, 1993.

CARPEAUX, O. M. Prosa e Ficção do Romantismo. In: GUINSBURG, J. (Org.). O Romantismo. São Paulo: Perspectiva, 1985.

FREUD, S. Sobre a Transitoriedade. (1916 [1915]). In: ESB. Rio de Janeiro: Imago, 1996. v. 14.

GOETHE, J. W. Os Sofrimentos do Jovem Werther. (P. Nasseiti, Trad.). 2a ed. São Paulo: Editora Martin Claret, 2008.

GUINSBURG, J. Romantismo, Historicismo e História. In: GUINSBURG, J. (Org.). O Romantismo. São Paulo: Perspectiva, 1985.

HAUSER, A. História social da arte e da literatura. (A. Cabral trad.). São Paulo: Martins Fontes, 1998.

KIEFER, B. O Romantismo na Música. In: GUINSBURG, J. (Org.). O Romantismo. São Paulo: Perspectiva, 1985.

NUNES, B. A visão romântica. In: GUINSBURG, J. (Org.). O Romantismo. São Paulo: Perspectiva, 1985.

RONCARI, L. O romântico brasileiro, raça, ego, nação: a procura da identidade brasileira. In: Literatura Brasileira: dos primeiros cronistas aos últimos românticos. 2 ed. São Paulo: EDUSP, 2002.

ROSENFELD, A.; GUINSBURG, J. Romantismo e Classicismo. In: GUINSBURG, J. (Org.). O Romantismo. São Paulo: Perspectiva, 1985a.

ROSENFELD, A.; GUINSBURG, J. Um Encerramento. In: GUINSBURG, J. (org.). O Romantismo. São Paulo: Perspectiva, 1985b.

VIZZIOLLI, P. O Sentimento e a Razão nas Poéticas e na Poesia do Romantismo. In: GUINSBURG, J. (Org.). O Romantismo. São Paulo: Perspectiva, 1985. 